\title{
PENGARUH EXERCISE RANGE OF MOTION (ROM) PADA PASIEN POST OPERASI FRAKTUR EKSTREMITAS TERHADAP INTENSITAS NYERI DI RSUD DR. SOEDARSO PONTIANAK
}

\author{
Baiturrahman $^{1}$, Ichsan Budiharto ${ }^{2}$, Yoga Pramana ${ }^{3}$ \\ ${ }^{1}$ Program Studi Keperawatan, Fakultas Kedokteran, Universitas Tanjungpura \\ baiturrahman@ @student.untan.ac.id ${ }^{2}$ RSUD Dr. Soedarso Pontianak ichsanbudiharto@ gmail.com ${ }^{3}$ \\ Program Studi Keperawatan, Fakultas Kedokteran, Universitas Tanjungpura yoga.idn@gmail.com
}

\begin{abstract}
ABSTRAK
Latar belakang : Nyeri post operasi fraktur adalah nyeri somatik dan terjadi deep somatic pain yang berasal dari otot tulang, persendian, dan jaringan ikat lainnya yang terjadi karena penumpukan zat kimia. Nyeri post operasi fraktur dapat dikurangi dengan exercise range of motion (ROM). ROM dapat menurunkan intensitas nyeri karena memperlancar sirkulasi darah, dan memelihara mobilitas persendian, mengurangi ketegangan, serta meningkatkan relaksasi.

Tujuan : Mengetahui pengaruh exercise range of motion (ROM) pada pasien post operasi fraktur ekstremitas terhadap intensitas nyeri di RSUD DR. Soedarso Pontianak.

Metode : Penelitian kuantitatif dengan desain quasy eksperiment, menggunakan metode pendekatan pre and post test without control. Penelitian ini menggunakan consecutive sampling dengan sampel 15 responden yang mengalami nyeri post operasi fraktur ekstremitas. Instrumen yang digunakan skala pegukuran nyeri nonverbal pain scale (NVPS) dan prosedur exercise range of motion (ROM). Setiap responden diberikan exercise range of motion (ROM).

Hasil : Sebagian besar responden berusia dewasa awal dan akhir dengan presentase 26,7\%. Perempuan merupakan jenis kelamin tertinggi 53,3\%, Pendidikan terbanyak adalah SMA 46,7\%, dan Suku terbanyak adalah Melayu 46,7. Analisis bivariat intensitas nyeri sebelum dan sesudah intervensi didaptkan nilai median (min-max) sebelum intervensi 5,00 (4-6) dan sesudah intervensi nilai median (min-max) 3,00 $(2-5)$ dan nilai $p=0,000(<0,05)$.

Kesimpulan : Ada pengaruh exercise range of motion (ROM) pada pasien post operasi fraktur ekstremitas terhadap intensitas nyeri di RSUD DR. Soedarso Pontianak.
\end{abstract}

Kata Kunci : Intensitas nyeri, Fraktur, Exercise Range Of Motion 


\begin{abstract}
Background : Post operative pain fractures are somatic pain and deep somatic pain originates from skeletal muscles, joints, and other connective tissues that emerge due to accumulation of potassium and acid lactic. Post operative pain fractures may be reduced through of exercise range of motion (ROM). ROM can decrease the intensity of pain because it improves blood circulation, and maintains joint mobility, reduces tension, and increases relaxation.

Objective : To measure the effect of exercise range of motion (ROM) to reduce pain in post-surgery patients of extremity fracture in RSUD DR. Soedarso Pontianak.

Methods : This study used with quasy experiment design, using pre and post test without control. This study used consecutive sampling with 15 respondents who experienced postoperative extremities fracture pain. Instruments used are pain scale nonverbal pain (NVPS) and standard operational procedure exercise range of motion (ROM).
\end{abstract}

Results : Most of the respondents were in early and late adult age groups with a percentage of $26.7 \%$. 46,7\% of respondents completed senior high school education with major ethnicity are Malays and 53,3\% of respondent completed woman. Bivariate analysis of pain intensity before and after intervention were median (min-max) 5,00 (4-6) before and median (min-max) 3,00 (2-5), and $p=$ $0,000(<0,05)$.

Conclusion : There was a significant of exercise range of motion (ROM) to reduce pain in post-surgery patients of extremity fracture in RSUD DR. Soedarso Pontianak.

Keywords : pain intensity, fracture, Exercise Range Of Motion

\section{PENDAHULUAN}

Fraktur atau sering dikenal dengan patah tulang adalah hilangnya kontinuitas tulang, retak atau patahnya tulang yang semulanya utuh, baik bersifat lokal maupun sebagian tulang yang biasanya disebabkan oleh trauma/rudapaksa atau tenaga fisik, kecelakaan, baik itu kecelakaan kerja, kecelakaan lalu lintas dan sebagainya yang ditentukan jenis dan luasnya fraktur. (Muttaqin, 2008; Lukman \& Ningsih, 2013; Depkes RI dalam Noorisa, Apriliwati, Aziz, \& Bayusentono, 2017).

World Health Organization (WHO), menyatakan kasus fraktur terjadi di dunia kurang lebih 13 juta orang pada tahun 2008, dengan angka prevalensi sebesar 2,7\% (Mardiono, 2010 dalam Djamal, Rompas \& Bawotong, 2015). Sementara pada tahun 2009 terdapat kurang lebih 18 juta orang dengan angka prevalensi sebesar 4,2\%. Tahun 2010 meningkat menjadi 21 juta orang dengan angka prevalensi 3,5\% (Mardiono, 2010 dalam Djamal, Rompas \& Bawotong, 2015). Tahun 2011-2012 WHO mencatat terdapat 5,6 juta orang meninggal dunia dan 1,3 juta orang menderita fraktur akibat kecelakaan lalu lintas (Noorisa, Apriliwati, Aziz, \& Bayusentono, 2017).

Dampak yang ditimbulkan pada fraktur antara lain keterbatasan 
aktivitas, adanya rasa nyeri akibat aktivitas saraf motorik dan sensorik pada jaringan fraktur. Nyeri adalah sesuatu hal yang bersifat subjektif, tidak ada dua orang sekalipun yang mengalami kesamaan rasa nyeri dan tidak ada dua kejadian menyakitkan yang mengakibatkan respon atau perasaan yang sama pada individu (Permana, Nurchayati, Herlina, 2015). Nyeri merupakan pengalaman sensori dan emosional yang tidak menyenangkan akibat dari kerusakan jaringan yang aktual atau potensial. Nyeri terjadi pada banyak proses penyakit atau bersamaan dengan beberapa pemeriksaan diagnostik, pembedahan dan pengobatan (Nurdin, Killing, Rottie, 2013).

Nyeri dapat mengakibatkan masalah pada sistem muskuloskeletal seperti keram otot, berkurangnya fungsi tulang, fatigue, dan keterbatasan gerak (Hinkle \& Cheveer, 2014). Rasa nyeri yang dialami pasien, membuat pasien takut untuk menggerakkan ekstremitas yang cedera, sehingga pasien cenderung untuk tetap terbaring lama, membiarkan tubuh tetap kaku. Oleh karena itu seorang perawat perlu memberikan informasi kepada pasien dan keluarga pasien tentang terapi nonfarmakologi yang bisa membantu pasien dalam menghilangkan atau mengurangi nyeri yaitu mobilisasi atau rentang gerak. (Smeltzer \& Bare, 2013; Lukman dan Ningsih, 2013).

Melakukan pergerakan ROM merupakan satu diantara teknik yang dapat dilakukan dalam menurunkan nyeri karena dapat memelihara kekuatan otot, memperlancar sirkulasi darah, dan memelihara mobilitas persendian. (Permana, Nurchayati, Herlina, 2015). Dengan dilaksanakan
ROM Exercise sejak dini juga dapat memperlancar peredaran darah sehingga oksigenasi pada luka menjadi lebih baik, asupan zat nutrisi dan juga obat dapat terserap dengan baik (Lestari, 2017).

ROM dapat juga meningkatkan kesegaran tubuh, memperbaiki tonus otot dan sikap tubuh, mengontrol berat badan, mengurangi ketegangan, serta meningkatkan relaksasi dan dapat juga mencegah terjadinya kontraksi, atropi otot, meningkatkan mobilisasi sendi, meningkatkan masa tulang, serta mengurangi kehilangan tulang, dan meningkatkan peredaran darah ke ekstremitas, mengurangi kelumpuhan vaskular, dan memberikan kenyaman pada klien (Lukman \& Ningsih, 2013; Smeltzer \& Bare, 2013).

Berdasarkan hasil wawancara dengan kepala ruangan bedah di RS DR. Soedarso didapatkan, perawat menggunakan teknik relaksasi dan distraksi untuk melakukan penanganan nyeri. Perawat seringkali nunggu instruksi dari dokter. Tindakan yang dapat dilakukan perawat adalah hanya melakukan ambulasi (miring kiri dan miring kanan). Berdasarkan wawancara dengan pasien didapatkan hasil, pasien mengeluh nyeri pada area fraktur yang terjadi, seperti nusuknusuk. Pasien merasa takut menggerakan bagian fraktur karena pasien beranggapan dapat memperparah atau memperlambat proses penyembuhan dan takut dapat memperberat rasa nyeri tersebut.

Berdasarkan uraian latar belakang diatas dengan ini peneliti mengangkat penelitian menenai Pengaruh Exercise Range Of Motion (ROM) Pada Pasien Post Operasi 
Fraktur Ektremitas Terhadap Intensitas Nyeri di RSUD DR. Soedarso Pontianak.

\section{BAHAN DAN METODE}

Jenis penelitian ini adalah penelitian kuantitatif, menggunakan desain penelitian quasi experiment yang menggunakan pendekatan pre and post test without control. Penelitian ini dilakukan di RSUD DR. Soedarso Pontianak kota Pontianak yang berlokasi di Jl. DR. Soedarso No.1, Bangka Belitung Laut, Pontianak Tenggara, Kota Pontianak, Kalimantan Barat. Sampel penelitian sebanyak 15 responden. Metode sample menggunakan non probability sampling dengan consecutive sampling. Instrumen yang digunakan untuk penelitian berupa alat tulis, SOP (Standard Operating Prosedure), lembar observasi skor nyeri NVPS. Skor nyeri yang digunakan yaitu skor nyeri sebelum dan sesudah diberikan intervensi. Intervensi dilakukan selama 3 hari dengan waktu 20 menit dan 5 kali pengulangan dalam setiap gerakan. Analisa data yang menggunakan frekuensi dan uji Wilcoxon untuk mengetahui perbedaan nyeri post operasi fraktur sebelum dan sesudah diberikan intervensi terapi exercise range of motion (ROM).
HASIL DAN PEMBAHASAN

Hasil penelitian yang dilakukan dengan melibatkan 15 responden yaitu sebagai berikut :

1. Analisa Univariat

Tabel 4.1

Karakteristik

Responden $(n=15)$

\begin{tabular}{|c|c|c|c|}
\hline \multicolumn{2}{|c|}{ Variabel } & $f$ & $\%$ \\
\hline \multirow[t]{5}{*}{ Usia } & Remaja Awal & 2 & 13,3 \\
\hline & Remaja Akhir & 3 & 20,0 \\
\hline & Dewasa Awal & 4 & 26,7 \\
\hline & Dewasa Akhir & 4 & 26,7 \\
\hline & Lansia Akhir & 2 & 13,3 \\
\hline \multirow{2}{*}{$\begin{array}{l}\text { Jenis } \\
\text { Kelamin }\end{array}$} & Laki-Laki & 7 & 46,7 \\
\hline & Perempuan & 8 & 53,3 \\
\hline \multirow[t]{5}{*}{ Pendidikan } & $\mathrm{SD}$ & 4 & 26,7 \\
\hline & SMP & 1 & 6,7 \\
\hline & SMA & 7 & 46,7 \\
\hline & D3 & 2 & 13,3 \\
\hline & $\mathrm{S} 1$ & 1 & 6,7 \\
\hline \multirow[t]{5}{*}{ Suku } & Batak & 1 & 6,7 \\
\hline & Dayak & 5 & 33,3 \\
\hline & Jawa & 1 & 6,7 \\
\hline & Madura & 1 & 6,7 \\
\hline & Melayu & 7 & 46,7 \\
\hline
\end{tabular}

pada tabel 4.1 didapatkan bahwa jumah responden dewasa awal dan dewasa akhir lebih banyak dibandingkan dengan usia lainnya yaitu sebanyak $26,7 \%$. Rentang Jenis Kelamin terbanyak yaitu perempuan sebanyak $53 \%$ dibandingkan lakilaki. Rentang Pendidikan tertinggi adalah SMA yaitu sebanyak $46 \%$ dibandingan pendidikan lainnya. Untuk rentang suku yang mengalamai nyeri post operasi fraktur di RSUD DR. Soedarso Pontianak adalah suku Melayu sebanyak 46,7\%. 
2. Analisa Bivariat

Tabel 4.3 Perbedaaan Skala Nyeri Sebelum dan Sesudah Exercise Range Of Motion (ROM) ( $\mathrm{n}=15)$

\begin{tabular}{cccc}
\hline $\begin{array}{c}\text { Variabel } \\
\text { Skala } \\
\text { Nyeri }\end{array}$ & $\begin{array}{c}\text { Median } \\
\text { (Min- } \\
\text { Max) }\end{array}$ & Mean \pm SD & $\begin{array}{c}\boldsymbol{p} \\
\text { Value }\end{array}$ \\
\hline $\begin{array}{l}\text { Sebelum } \\
\text { Sesudah }\end{array}$ & $5,00(4-6)$ & $4,80 \pm 0,676$ & 0,000 \\
\hline
\end{tabular}

Berdasarkan analisis dari 15 responden pada tabel 4.3 didapatkan bahwa nilai $p$ Value yaitu 0,000 yang berarti $\mathrm{H}_{\mathrm{o}}$ ditolak dan $\mathrm{H}_{\mathrm{a}}$ diterima. Dapat disimpulkan bahwa terdapat perubahan skala nyeri sebelum dan sesudah diberikan intervensi exercise range of motion selama 3 hari pada responden.

\section{PEMBAHASAN}

\section{Karakteristik}

Berdasarkan Usia dan Jenis Kelamin

Berdasarkan hasil penelitian yang telah dilakukan pada pada pasien post operasi fraktur ekstremitas didapatkan hasil bahwa pasien yang terbanyak mengalami post operasi fraktur ekstremitas adalah pada usia dewasa awal dan dewasa akhir. Masa dewasa ialah dimana masa yang memerlukan kebutuhan kehidupan tinggi sehingga kebanyakan masa dewasa banyak melakukan aktivitas diluar rumah seperti bekerja, mengendarai sepeda motor sehingga akan beresiko terjadinya fraktur. Dengan deminikian dapat disimpulkan usia terbanyak yang terjadi pada pasien post operasi fraktur adalah usia dewasa.

Berdasarkan penelitian Mandagi, Bidjuni, \& Hamel (2017) tentang Karakteristik Yang Berhubungan Dengan Tingkat Nyeri
Pada Pasien Fraktur di Ruang Bedah Rumah Sakit Umum GMIM Bethesda Tomohon didapatkan hasil responden terbanyak pada usia dewasa sebanyak 16 responden $(38,1 \%)$, sedangkan pada masa remaja sebanyak 14 responden $(33,3 \%)$ dan masa lansia sebanyak 12 responden $(28,6 \%)$. Usia merupakan faktor sangat penting dalam mempengaruhi nyeri pada seseorang. Dewasa muda cenderung sering terjadinya kecelakaan, hal ini dikarenakan penggunaan kendaraan bermotor sehingga akan mengakibatkan nyeri pada seseorang tersebut (Muscari 2006 dalam Mandagi, Bidjuni, \& Hamel 2017).

Berdasarkan hasil penelitian yang telah dilakukan pada pada pasien post operasi fraktur ekstremitas didapatkan hasil bahwa pasien yang terbanyak mengalami post operasi fraktur ekstremitas pada jenis kelamin yaitu perempuan. Hal ini dipengaruhi cara mengendarai sepeda motor, bagi wanita masih banyak keragu-raguan dalam mengendarai sehingga beresiko mengalami fraktur.

Berdasarkan penelitian Desiartama \& Aryana (2017), Gambaran Karakteristik Pasien Fraktur Femur Akibat Kecelakaan Lalu Lintas Pada Orang Dewasa Di Rumah Sakit Umum Pusat Sanglah Denpasar Tahun 2013, didapatkan hasil laki-laki menjadi angka kejadian tertinggi sebanyak $69,1 \%$ dibandingkan perempuan 30,9\%. Djamal, Rompas, \& Bawotong (2015) menyatakan dalam penelitian nya angka kejadian fraktur pada kelompok intervensi terjadi kesamaan antara laki-laki dan wanitai yaitu sebanyak $50,0 \%$. 
Fraktur dapat terjadi pada jenis kelamin laki-laki ataupun perempuan dan pada usia berapapun pada penelitian ini angka kejadian terbesar adalah perempuan dibandikan laki-laki. Tingkat kejadian fraktur dapat meningkat dengan terjadinya peningkatan usia dan sering berhubungan dengan olahraga, pekerjaan, atau luka yang disebabkan oleh kecelakaan kendaraan bermotor (Lukman \& Ningsih, 2013; Khan, Mukherjee, Kumar, \& Basha, 2015).

\section{Karakteristik Responden Berdasarkan Pendidikan dan Suku} Berdasarkan hasil penelitian yang telah dilakukan pada pada pasien post operasi fraktur ekstremitas didapatkan hasil bahwa pasien yang terbanyak mengalami post operasi fraktur ekstremitas pada pendidikan terakhir yaitu SMA. Hal ini dikarenakan tingkat pendidikan SMA merupakan populasi terbanyak yang mengalami fraktur di RSUD DR. Soedarso Pontianak. Kejadian fraktur dapat terjadi pada tingkat pendidikan rendah ataupu tinggi. Sebagian besar pada tingkat pendidikan SMA mengendarai sepeda motor dengan kecepatan diatas ratarata dan kebanyakan melakukan kegiatan lebih banyak diluar seperti mengendarai motor, mobil, dan bekerja seperti buruh bangunan, dan bekerja di perusahaan alat berat sehingga akan beresiko akan terjadinya fraktur.

Berdasarkan

penelitian

Mintarsih \& Nabhani (2016) tentang Teknik Relaksasi Nafas Dalam Terhadap Penurunan Nyeri Laki Dan Perempuan Post Operasi didapatkakn hasil tingkat pendidikan SMA merupakan kejadian terbanyak yaitu 19 responden $(63,3 \%)$.

Kejadian fraktur biasa terjadi pada individu dengan tingkat pendidikan tinggi maupun pendidikan rendah. Karena pendidikan SMA lebih banyak pada orang dengan tingkat ekonomi bawah yang mengharuskan mereka untuk lebih banyak beraktifitas diluar seperti mengendarai sepeda motor yang berisiko tinggi untuk mengalami cedera/fraktur (Permana, Nurchayati \& Herlina, 2015).

Berdasarkan hasil penelitian yang telah dilakukan pada pada pasien post operasi fraktur ekstremitas didapatkan hasil bahwa pasien yang terbanyak mengalami post operasi fraktur ekstremitas pada suku adalah suku melayu. Badan Perencanaan Pembangunan Daerah Kota Pontianak (2018), menyatakan bahwa daerah kota Pontianak suku bangsa terbanyak adalah suku melayu sebanyak 34,50\%.

Pada saat ini belum di nyatakan kejadian fraktur ekstremitas dan nyeri post operasi fraktur ekstremitas lebih banyak pada suku tertentu. DeLaudne dan Ladner (2012) dalam Yusliana, Misrawati, \& Safri (2015) menyatakan bahwa faktor yang mempengaruhi nyeri seseorang diantarnya usia, jenis kelamin, dan kebudayaan. Suku melayu lebih menahan diri dari rasa sakit yang dirasakan dibandikan suku lainnya. Suharti, 2013 dalam Yusliana, Misrawati, \& Safri (2015), menyatakan Suku berperan penting terhadap respon seseorang pada nyeri. Keyakinan dan nilai-nilai budaya mempengaruhi cara individu mengatasi nyeri. Individu mempelajari apa yang diharapkan dan 
apa yang diterima oleh kebudayaannya. Ada perbedaan makna dan sikap yang dikaitkan dengan nyeri di berbagai kelompok budaya.

\section{Pengaruh Exercise Range of Motion (ROM) Pada Pasien Post Operasi Fraktur Ektremitas Terhadap Intensitas Nyeri di RSUD DR. Soedarso Pontianak}

Hasil penelitian yang telah dilakukan oleh peneliti pada 15 responden yang diberikan intervensi. Responden diberikan exercise range of motion selama 3 hari dengan pengulangan 5 kali tiap gerakan selama 20 menit. Responden diberikan analgesik ketorolak pada hari pertama/keluar dari ruang operasi atau ketika responden mengatakan nyeri. Pengukuran intensitas nyeri pada responden menggunakan Non Verbal Pain Scale (NVPS). Hasil uji Wilcoxon pre-test dan post-test dilakukan exercise range of motion di RSUD DR. Soedarso Pontianak.

Berdasarkan hasil penelitian yang telah dilakukan oleh peneliti, responden yang mengalami nyeri menggunakan Non Verbal Pain Scale (NVPS) didapatkan hasil rata-rata pre-test diakukan exercise range of motion sebesar 4,80, sedangkan intensitas nyeri post-test diberikan exercise range of motion didaptkan hasil rata-rata 3,13. Responden mengatakan nyeri pada area fraktur yang dilakukan operasi, responden mengatakan sulit melakukan untuk pergerakan dalam melakukan aktifitas atau kegiatan di atas tempat tidur, kelemahan, adanya pembengkakan, dan sering terjadinya spasme/keram baik pada malam atau shubuh hari dan adanya luka akibat prosdur tindakan operasi. Hal ini sesuai dengan teori bahwa dampak dari trauma fraktur yang dirasakannya adalah keram otot, berkurangnya fungsi tulang, fatigue, dan keterbatasan gerak yang diakibatkan dari kerusakan jaringan yang aktual dan potensial, dan adanya aktivitas saraf motorik dan sensorik pada jaringan fraktur (Smeltzer \& Bare, 2015; Hinkle \& Cheveer, 2014; Bullock \& Henze, 2000).

Berdasarkan hasil penelitian, responden mengalami nyeri pre-test intervensi exercise range of motion dimana terjadinya tidak nyaman pada saat di atas tempat tidur, spasme/keram pada malam dan shubuh hari, sulit untuk bergerak, terjadinya pembengkakan dan takut untuk melakukan pergerakan pada area fraktur dikarena responden beranggapan jika digerakan takut untuk berpengaruh pada nyeri yang semakin kuat. setelah dilakukan exercise range of motion nyeri dan bengkak responden berkurang dan membaik. Peneliti juga menyarankan pada responden untuk selalu melatih pada area fraktur yang post operasi.

Rasa nyeri yang dirasakan oleh responden terjadi pada tahap tranduksi dimana mengacu pada proses luka sayatan pembedahan yang mengaktifkan sayaraf aferen primer (nociceptors) yang dari somatik (Muskuloskeltal) dimana neuron ini akan merespon terhadap rangsangan bahaya dari kerusakan jaringan mekanis yaitu insisi. Rangsangan bahaya tersebut akan melepas sejumlah senyawa satu siantaranya adalah prostaglandin, yang menyebabkan nyeri di sepanjang jalur nyeri. Prostaglandin adalah senyawa lipid yang memulai respons inflamasi 
yang meningkatkan pembengkakan dan nyeri di lokasi cedera. Bentuknya saat enzim phospholipase memecah fosfolipase menjadi asam arakidonat. Pada gilirannya, enzim siklooksigenase (COX) bekerja pada asam arakidonat untuk menghasilkan prostaglandin (Pasero \& Potenoy, 2011; Vadivelu, Whitney, \& Sinatra, 2009; Pasero, Portenoy, \& McCaffery 2011 dalam Hinkle \& Cheveer, 2014).

Rasa nyeri post operasi fraktur yang dirasakan responden adalah deep somatic pain hasil ini disebabkan karena terjadinya penumpukan bahan kimia yaitu potassium atau asam laktat hal tersebut disebabkan adanya gangguan jaringan dimana terjadinya kekurangan oksigen, glukosa atau insulin pada saat proses pembentukan jaringan baru yang dilakukan oleh potassium karena potassium merupakan kation utama intrasellular yang secara langsung mempengaruhi rangsangan saraf dan otot dan berkontribusi terhadap tekanan osmotic intraseluler. (Hinkle \& Cheveer, 2014; Bullock \& Henze, 2000).

Berdasakan penelitian ini Exercise range of motion post operasi fraktur ekstremitas yang mengalami nyeri, post-test exercise range of motion selama 3 hari intervensi terbukti terjadi penurunan intensitas nyeri menggunakan Non Verbal Pain Scale (NVPS). Hal ini disebabkan pada saat pembentukan prostaglandin yang menyebabkan respon pembengkakan dimana sirkulasi oksigenisasi terganggu dan peredaran darah juga akan terganggu yang akan membuat terjadinya penumpukan zat kimia potassium atau asam laktat, dengan dilakukannya exercise range of motion dapat membantu menghancurkan dari penumpukan zat kimia potassium atau asam laktat sehingga peredaran darah lancar, oksigenisasi menjadi lebih baik, meningkatkan mobilisasi sendi, meningkatkan masa tulang memberikan kenyamanan pada responden, meningkatkan relaksasi serta dapat membantu penyerapan nutrisi dan obat dapat terserap dengan baik.

Penelitian terkait yang dilakukan oleh Permana, Nurchayati, dan Herlina (2015) berjudul Pengaruh Range Of Motion (ROM) Terhadap Intensitas Nyeri Pada Pasien Post Operasi Fraktur Ekstremitas Bawah didapatkan hasil bahwa ada rata-rata intensitas nyeri sebelum dilakukan ROM yaitu 4,71 sedangkan rata-rata intensitas nyeri setelah dilakukan ROM yaitu 3,27. Hasil penelitian Rustiawati, Karyati, dan Himawan (2013) tentang Efektivitas Ambulasi Dini terhadap Penurunan Intensitas Nyeri pada Pasien Post Operasi Laparatomi di RSUD Kudus didapatkan hasil bahwa dengan dilakukan ambulasi post operasi laparatomi dapat menurunkan intensitas nyeri.

Penelitian Wahyono dan Utomo (2016) tentang Efek Pemberian Latihan Hold Relax Dan Penguluran Pasif Otot Kuadrisep Terhadap Peningkatan Lingkup Gerak Fleksi Sendi Lutut Dan Penurunan Nyeri Pada Pasien Pasca ORIF Karena Fraktur Femur 1/3 Bawah Dan Tibia 1/3 Atas didapatkan hasil bahwa latihan hold relax maupun latihan penguluran pasif otot kuadrisep berpengaruh terhadap penurunan nyeri dan 
peningkatan lingkup gerak sendi (LGS) fleksi lutut. Sejalan dengan penelitian Mintarsih dan Nabhani (2015) tentang Pengaruh Latihan Range Of Motion Terhadap Peningkatan Kemampuan Fungsi Ekstremitas Sendi Lutut Pada Pasien Post Operasi (Orif) Fraktur Femur didapatkan hasil bahwa ada pengaruh latihan ROM terhadap kemampuan fungsi ektremitas sendi lutut pada pasien post operasi fraktur femur.

\section{SIMPULAN DAN SARAN}

Simpulan

Responden dalam penelitian ini usia tertinggi dalam penelitian ini adalah masa dewasa awal dan dewasa akhir yaitu $26,7 \%$, mayoritas jenis kelamin tertinggi adalah perempuan yaitu $53,3 \%$, sedangkan tingkat pendidikan SMA merupakan tertinggi dalam penelitian ini yaitu $46,7 \%$, dan suku tertinggi dalam penelitian ini adalah melayu yaitu $46,7 \%$.

Median skala nyeri dengan menggunakan Non Verbal Pain Scale (NVPS) sebelum intervensi (pre-test) yaitu 5,00, dan setelah intervensi (post-test) yaitu 3,00. Hasil pre-test terdapat skala nyeri tertinggi adalah nyeri sedang sebanyak $100 \%$. Hasil post-test terdapat skala nyer tertinggi adalah nyeri ringan sebanyak $66,7 \%$. Dalam penelitian ini tidak ditemukan responden dengan skala nyeri berat.

Ada pengaruh exercise range of motion terhadap intensitas nyeri pada pasien post operasi fraktur esktremitas di RSUD DR. Soedarso Pontianak dengan nilai $p$ value 0,000 $(<0,05)$.
Saran

Implikasi keperawatan dari penelitian ini yaitu dapat dijadikan sebagai terapi alternatif non farmakologi untuk menurunkan intensitas nyeri tanpa memberikan efek samping seperti halnya dengan terapi farmakologi sehingga akan meningkatkan status kesehatan. Perawat sebagai care giver diharapkan mampu memberikan intervensi yang optimal bagi klien, khususnya dalam menangani nyeri baik itu nyeri ringan hingga nyeri berat pada klien post operasi fraktur post operasi ekstremitas. Pada dasarnya selain bisa mengatasi nyeri, exercise range of motion juga dapat memperbaiki jaringan yang luka, dan kekuatan otot pada post operasi fraktur sehingga sebagai perawat khususnya dapat memenuhi kebutuhan dasar klien.

Penelitian ini dapat dijadikan pengetahuan dan intervensi untuk pengembangan intervensi pencegahan pada nyeri post operasi fraktur ekstremitas serta dapat menjadi media pembelajaran berbasis bukti khususnya pada keperawatan muskuloskeletal.

\section{DAFTAR PUSTAKA}

Bappeda (2018) Sosial Budaya. Diakses 15 Juli 2018, dari http://bappeda.pontianakkota.go.id/st atis-24-sosialbudaya.html

Bullock, B. L. \& Henze, R. L. (2000). Focus On Pathophysiology. United States of American: Lippicott Williams \& Wilkins

Desiartama, A., \& Aryana, I. W. (2017). Gambaran Karakteristik 
Pasien Fraktur Femur Akibat Kecelakaan Lalu Lintas Pada Orang Dewasa Di Rumah Sakit Umum Pusat Sanglah Denpasar Tahun 2013. E-Jurnal Medika

Udayana, 6(5).

Djamal, R., Rompas, S., \& Bawotong, J. (2015). Pengaruh Terapi Musik Terhadap Skala Nyeri Pada Pasien Fraktur di Irina A RSUP Prof. Dr. RD Kandou Manado. Jurnal Keperawatan, 3(2).

Djamal, R., Rompas, S., \& Bawotong, J. (2015). Pengaruh Terapi Musik Terhadap Skala Nyeri Pada Pasien Fraktur di Irina A RSUP Prof. Dr. RD Kandou Manado. Jurnal Keperawatan, 3(2).

Hinkle, J. L., \& Cheever, K. H. (2014). Brunner \& Suddart Texbook Of Medical-Surgical Nursing $\left(13^{\text {th }}\right.$ ed.). China: Wolters Kluwer Health | Lippincott Williams \& Wilkins

Khan, A., A.L Kukherjee, M. K. K., SK Mastan B. (2015). Study of Functional Outcome of Surgical Management of Proximal Humerus Fracture by Various Modalities. IOSR Journal of Dental and Medical Sciences (IOSR-JDMS), 14 (6); eISSN: 2279-0853, p-ISSN: 22790861, DOI: 10.9790/0853-14669199

Lestari, Y. E. D. (2017). Pengaruh Rom Exercise Dini Pada Pasien Post Operasi Fraktur Ekstremitas Bawah (Fraktur Femur Dan Fraktur Cruris) Terhadap Lama Hari Rawat Di Ruang Bedah Rsud Gambiran Kota Kediri. Jurnal Ilmu Kesehatan, 3(1), 34-40.
Lukman \& Ningsih, N. (2013). Asuhan Keperawatan Pada Klien dengan Gangguang Sistem Muskuloskeletal. Jakarta: Selemba Medika. ISBN 9789793027982

Lukman \& Ningsih, N. (2013). Asuhan Keperawatan Pada Klien dengan Gangguang Sistem Muskuloskeletal. Jakarta: Selemba Medika. ISBN 9789793027982

Mandagi, C. A., Bidjuni, H., \& Hamel, R. S. (2017). Karakteristik Yang Berhubungan Dengan Tingkat Nyeri Pada Pasien Fraktur Di Ruang Bedah Rumah Sakit Umum Gmim Bethesda Tomohon. Jurnal Keperawatan, 5(1).

Mintarsih, S., Dan Nabhani. (2016). Pengaruh Latihan Range Of Motion Terhadap Peningkatan Kemampuan Fungsi Ekstremitas Sendi Lutut Pada Pasien Post Operasi (Orif) Fraktur Femur. Seminar Nasional, Hasil Hasil Penelitian Dan Pengabdian Lppm Universitas Muhammadiyah Purwokerto. ISBN : 978-602-149303-8. Diakses: 22 Maret 2018, dari Jhptump-Ump-Gdl-Srimintars-1431$\underline{1-\mathrm{E} 07-18--) . P d f}$

Muttaqin, A. (2008). Asuhan keperawatan Klien Gangguan sistem muskuloskeletal. Editor Eko karyuni, Jakarta: EGC.

Noorisa, R., Apriliwati, D., Aziz, A., \& Bayusentono S. (2017). The Characteristic Of Patients With Femoral Fracture In Department Of Orthopaedic And Traumatology Rsud Dr. Soetomo Surabaya 2013 - 2016. Journal of Orthopaedi \& 
Traumatology Surabaya, 6(1); ISSN 2460-8742

Nurdin, S., Killing, M., Rottie J. (2013). Pengaruh Teknik Relaksasi Terhadap Intensitas Nyeri Pada Pasien Post Operasi Fraktur Di Ruang Irnina A Blu Rsup Prof Dr. R.D Kandou Manado. e-journal keperawatan, 1(1)

Permana, O., Nurchayati S., \& Herlina. (2015). Pengaruh Range Of Motion (ROM) Terhadap Intensitas Nyeri Pada Pasien Post Operasi. JOM, 2(2).

Rustianawati, Y., Karyati, S., \& Himawan, R. (2013). Efektivitas ambulasi dini terhadap penurunan intensitas nyeri pada pasien post operasi laparatomi di RSUD Kudus. Jurnal Ilmu Keperawatan dan Kebidanan, 4(2).
Smeltzer dan Bare. (2013). Buku Ajar Keperawatan Medikal Bedah Brunner \& Suddart $\left(8^{\text {th }}\right.$ ed. Vol. $\left.3^{\text {rd }}\right)$. Jakarta: EGC.

Smeltzer, S. C., \& Bare B. G. (2015). Buku Ajar Keperawatan Medikal Bedah Brunner \& Suddarth $\left(8^{\text {th }}\right.$ ed. Vol. $\left.1^{\text {st }}\right)$. Jakarta: EGC

Wahyono, Y., \& Utomo, B. (2016). Efek Pemberian Latihan Hold Relax dan Penguluran Pasif Otot Kuadrisep Terhadap Peningkatan Lingkup Gerak Fleksi Sendi Lutut dan Penurunan Nyeri pada Pasien Pasca Orif Karena Fraktur Femur 1/3 Bawah dan Tibia 1/3 Atas. Interest: Jurnal Ilmu Kesehatan, 5(1).

Yusliana, A., Misrawati, \& Safri. (2015). Efektivitas Relaksasi Benson Terhadap Penurunan Nyeri Pada Ibu Postpartumsectio Caesarea. Jurnal Online Mahasiswa Program Studi Ilmu Keperawatan Universitas Riau, 2(2), 944-952. 